\title{
Platfospheres and sociocultural explosion of Web 2.0: The commercial centre of the digital semiosphere
}

\author{
Kristian Bankov ${ }^{1}$
}

\begin{abstract}
This paper explores digital culture with the tools of cultural semiotics in general, and then employing the semiosphere model in particular. Web 2.0 platforms are taken as the major cultural dispositive of our time, as the most representative way in which the internet shapes digital culture. Most of the global population is currently immersed in digital culture. In the first part of the paper the striking similarities between Web 2.0 platforms and the semiosphere are explored and equivalences between the elements of the classic (Lotman's) semiotic model and these platforms, or platfospheres, are identified. The second part explores the fundamental difference between the "genetic code" at the centre of the semiosphere (as conceived by Lotman), and the computer code and commercial algorithms at the core of the platfospheres that are responsible for their cultural operation. Then the parallels are examined that arise between the past cultural reality, in which the intellectual elite and academics were the driving force of culture, and the contemporary proactive (or even aggressive) core of the platfospheres, in which secret and patent-protected algorithms shape a cultural reality exclusively motivated by the logic of commercial success.
\end{abstract}

Keywords: Juri Lotman; semiosphere; social media algorithms; digital culture; economy

\section{Introduction}

Two of the major semiotic models of culture, conceived before the advent of the internet, proved prophetic in the way global networks have changed sociocultural reality. These are Umberto Eco's encyclopedia and Juri Lotman's semiosphere, both models as open and dynamic as the internet. Here, I develop the theoretic premises of these classic semiotic models to render them applicable to digital cultural

1 Sichuan University, China; South-East European Centre for Semiotic Studies, New Bulgarian University, Sofia, Bulgaria. E-mail: kbankov@nbu.bg. 
reality, with a particular focus on the most popular and influential platforms, namely Facebook, Instagram, YouTube and the Google search. The semiosphere model assumes a central role in the mechanism by which the logic of digital interaction absorbs the sociocultural sphere, as well as in the way in which the commodification of cultural experiences is becoming the major source of cultural innovation.

The approach itself is not altogether new. Important semiotic conceptualizations of the digital semiosphere come from Luis Bruni $(2011,2015)$. The context of his approach is ethical, and the research is a good example of ecosemiotic critique. Lotman's and Bateson's insights are employed as a theoretical frame to demonstrate that (1) the digital semiosphere is profoundly different from the semiosphere "as we have understood it until now" (Bruni 2015: 112); (2) the acritical and vehement promotion of creativity and innovation within digital culture led by the only logic of economic profit brings about a cognitively unsustainable cultural environment (Bruni 2015: 114); (3) such "intellectual decadence" is harmful not only for the culture itself, but for the "life-support systems in which cultures are embedded" (Bruni 2015: 114, 113).

Such a framework overlaps with my suggestions on (1) and (2), although for other reasons I chose the definition by Rifkin (2000: 7) in the conclusions; notwithstanding, the basic message remains the same. Since my overall intention is theoretical rather than ethical I am not drawing deep ethical conclusions and judgements as does Bruni, but these are certainly not contradictory to my point.

The approach also takes inspiration from Ibrus and Torop's (2015) work "Remembering and reinventing Juri Lotman for the digital age". The paper outlines many possible research directions, leaving economic and commercial problematics aside. This is the case with Lotman's whole opus, as in his sociopolitical situation the commercial and the cultural were considered alien to each other. From the perspective of the humanities, and as I have been discussing elsewhere (Bankov 2020), semiotic research since Lotman has resisted studying the deep semiosic principles of economic value, limiting its interest to superficial inquiries into marketing and consumer phenomena. Ibrus (2014) as well as Ibrus and Scolari (2012) are some of the pioneers who have been carrying out cultural research $v i s-\grave{a}$-vis the new digital, creative industries and the market of technological innovation. The main difference between their approach and mine consists in my intention to cleave more tightly to semiotic theory, and to the semiosphere model in particular.

However, the author whose work is most relevant for the present research is John Hartley. He is the real pioneer in applying Lotman's models, and especially that of the semiosphere, for an elaborate theoretical framework of the new economy. Hartley has been drawing on Lotman since the late 1990s, until some 
years ago he became immersed in the core biosemiotic theory, developed by the heirs of Lotman in Tartu and their Danish colleagues (Hartley, Potts 2014: 138-142). The role of Lotman is central for Hartley and his co-authors, as the concept of the semiosphere gives a scientific foundation for the definition of a new disciplinary approach, namely "cultural science".

Cultural science has been elaborated to meet the new cultural realities of the digital age when the cultural and the commercial have come to overlap with each other almost entirely. As a research approach, it differs from the tradition of the humanities as a critique in general and the cultural studies in particular (Hartley 2012: 9-10, 183). What makes the model of the semiosphere particularly adapted to Hartley's project is its holistic set up for cultural analysis (Hartley 2012; Hartley, Potts 2014; Hartley, Wen, Li 2015; Potts et al. 2008). Hartley's approach in modelling the creative industries adopts a global, networked and evolutionary understanding of creativity and its transformation into economic value. Such an approach differs from the more conventional individualistic understanding of creativity and entrepreneurship in the same way in which Lotman's concept of the semiosphere comes to oppose those approaches, starting from the sign or a separate sign system, and only afterwards reconstructing the whole from its parts. The notion of newness that is crucial for the cultural science finds a direct equivalent in the mechanism of the semiosphere, where the continuous creation of significant novelty is the natural condition of life of culture and not an accident of creativity.

The present paper fits the framework of the cultural science and elaborates a few aspects of digital economy, left unexplored by Hartley and his co-authors. One such aspect is the role of the algorithms at the centre of the digital semiosphere; the other one is the main focus on the social media platforms as the most essential expression of the digital age, which is why less attention is paid to the creative industries in general.

\section{The hypothesis}

My main hypothesis is that extending the semiosphere model of culture to address the cultural mechanism of Web 2.0 Internet platforms, positioning these as different semiospheres, will (1) prove in a different, consistent and concrete way the "digital" validity of Juri Lotman's semiotic theory; (2) lead to valid insights in regard to the semiotics of these platforms, also relevant for other disciplines and (digital) professionals; and (3) give essential directions for developing a new digital semiotic paradigm, akin to our contemporary cultural reality and emancipated from the dogmatic application of classic semiotic models. I conclude with a 
diagnosis as to whether the Internet (and its Web 2.0 phase in particular) changed the very core structure of the global cultural tissue, with an impact comparable to that of the invention of print or if these changes are merely a matter of expression and have not influenced our "central semiotic system".

\section{Method of research}

The closest established method is grounded theory. As it was mentioned above, the paper may be considered a contribution in the newly established field of culture science (Hartley 2012; Hartley, Potts 2014). My major concern is the validity of a well-established theoretical model and its non-dogmatic application to a new cultural reality in respect to the cultural reality of its conception. The theoretical reflection is essentially deductive, thus subject to control by logical means, and its reference to new digital reality is supported by statistical data and documented facts. As to the authors who have methodologically inspired my research, and are implicitly present in many of its parts, I mention Umberto Eco and Jeremy Rifkin (mostly from Rifkin 2000).

\section{The semiosphere model}

The semiosphere model is a model for the social life of culture, one inspired by a model of biological life. It is a fruitful and thought-provoking piece of semiotic theory, the synthesis of Juri Lotman's semiotic work. Contrary to Hartley, I think its relevance does not rely on its scientific rigour: I would instead label it as what Bergson (1992) called a "deep philosophic intuition" and what Foucault (1977) described as a "foundation of discursivity", even as a stroke of genius in resemblance to the Peircean abduction in a scientific discovery. It is the task of Lotman's followers to produce more rigorous outcomes, which is where I aim to position this contribution, together with the other quoted authors. Lotman offered many concrete examples that illustrate the semiosphere model, but they are so many and heterogenous that the reader remains with the impression that anything can be seen as a semiosphere - from a given culture to global human culture, from a literary genre to art as a whole, from the individual mind to the work of any known and unknown author, from a single movie to the whole technology of mechanical image reproduction, and beyond. The interchangeability of the various elements constituting the semiosphere cause specific difficulties for framing the model theoretically: 
One and the same centre of the semiosphere can be ane and the same time both active and 'receiving', one and the same space of the semiosphere can be both in one sense a centre and in another sense a periphery; attractions provoke rejections, and borrowings provoke originality. (Lotman 1990: 150)

All this is to stress that, when I refer to the model of the semiosphere, I am referring to a partial interpretation of it for which I take responsibility. I try to be as faithful as possible to the model's core assumptions, but for that purpose I leave aside its great variety to focus on a simplified and coherent version. While similar and successful attempts to define the semiosphere have been made by many prominent semioticians, these still do not amount to identifying the canon of Lotman's model.

The foundation of the semiosphere model essentially relies on three fundamental elements - border, periphery, centre, and on three concepts which enact the dynamic relation between those elements - asymmetry, translation, and text. I start from Lotman's assumption that culture consists in all the non-genetically inherited information that humans transmit cross-generationally. Although he used the term 'information' to define culture, we must substantially elevate the nature of what is culturally transmitted, which may include even the enforcement on the new-born child to adapt his or her natural physiological needs to the rhythm of life of the socially organized world of the parents. From my point of view, culture might be seen as everything which helps humans adapt their genetically constituted being to the standards of social life. The biosphere (Vladimir Vernadsky's concept which inspired Lotman - see Hartley 2015, Ch 2) provides the resources for survival of the genetically constituted individual, and the semiosphere provides the conditions for survival of the socio-culturally constituted individual.

In Lotman's view, the semiosphere and the biosphere work in a similar way, as well as a given culture, the individual mind, the living cell or an entire ecosystem. The semiosphere model bridges these two disciplinary separate universes. Ontogenetically and phylogenetically, natural language has a privileged role in the semiotic construction of cultures and social individuals. Verbal language, with its superiority to any other sign system's formal grammar, positions itself in the centre of the system, as is the cell's nucleus (Lotman 1990: 127), bearer of the most formal unit in the living universe - its DNA. From this difference derives one of the analogy's core distinctions: whereas the biological DNA is stable in structure, splitting symmetrically each time, the structure of language evolves slowly but unceasingly.

In this model there is a complex dialectics between language and text. According to Eco (1990: $\mathrm{x}$-xi) and Nöth (2015) whom I follow in this regard, in 
the first period of his semiotic theory Lotman adopted a rigorous structuralist approach, giving prevalence to the linguistic code over the text. However, given his gradual theoretic maturation towards the semiosphere model, he eventually overturned the dialectic towards prevalence of the text. The text thus becomes an autonomous semiotic operator within culture which has an active role in its innovation, and in the transport of significance from the periphery to the centre. If we return to the analogy of living organisms, the semiosphere's centre, formed by a given and well-structured state of language, eats texts and, as nutritionists say, it gradually becomes what it eats. Texts are original models of the world, their attractiveness and popularity gradually dissolving them as norms, thus substituting dying residual expressive forms. As Lotman (1990: 150) puts it, "the energy of the semiosphere is the energy of information, the energy of Thought". This would mean people's minds are perpetual semiotic engines that need semiotic metabolism to survive. The semiotic metabolism in Lotman's system is translation.

Translation is a universal semiotic process of transformation, wherein one semiotic form/content is transformed into another (Lotman 1990: 127). The translation that interests Lotman is asymmetrical as it always introduces novelty, new messages, and new information to the system. Contrary to the common notion, in Lotman's conceptualization, translation is more valuable when it is more creative, when the gap between the source text and the target text is greater and the latter acquires unique and autonomous semiotic features. Translation is at work whenever we talk or write about something, when we structure meaningful unity "in other words," or when we render an aesthetic or philosophic inspiration in written discourse. Whatever our thought deals with, it unavoidably starts from somewhere and it brings about a new semiotic occurrence, as a translation. The negation of translation is not so much wrong interpretation, but rather the instance when translation is predetermined in only one possible correct target text, meaning that the reverse translation would bring semiosis to the exact source text. Lotman (1990: 14) illustrates this through Wittgenstein's aphorism that "within logic you cannot say anything new".

The model of the semiosphere analogizes culture to a living organism. Its major theoretical contribution is that of showing the "organic" mechanism of its own semiotic life. Like in the living cell, the centre/nucleus consumes what comes from the periphery. The periphery is the semiotic space where fresh, active and interesting cultural processes take place. The force of gravity of the centre continuously brings semiotic content inwards, translating it into new forms with increasing structurality. The centre's gravitational force comes from the natural predisposition of our minds to think rather than to vegetate. The translation, the semiotic metabolism of the system, carries semiotic energy from the periphery 
towards the centre. Consuming that energy, the centre rejuvenates itself, updates itself, becomes more efficient and voracious for new input from the periphery. The semiotic consumption of the periphery's resources consists in their normalization, canonization, "grammatization", the worn-out metaphors (Derrida 1982) which assume conventional use in the everyday speech of all:

'Common to all', $[\ldots]$ is the most important feature of semiotic systems of the centre. The periphery is brightly coloured and marked, whereas the nucleus is 'normal', i.e. lacking in colour or scent, it 'simply exists'. So the victory of a semiotic system involves it shifting to the centre and an inevitable 'toning down'. (Lotman 1990: 141)

To illustrate the model as it has previously been outlined, I use an example from cinema. It is not by chance that the movie Matrix (1999) is one of the movies most quoted by semioticians. It brought a huge innovation in the action movie inventory of expressive means, with its peak in digital special effects. The movie was launched to public interest in 1999, and quickly became a commercial success. But contrary to most of the other blockbusters it has created a tendency encompassing not only SF but also fantasy and superhero films, which have subsequently come to dominate the industry. ${ }^{2}$ I do not explore the details of specific FX innovations in Matrix. The mechanism of their overall impact is of concern here.

From interviews and film analyses we know that the inspiration for the visual realization of the movie came from certain Japanese anime productions. The plot was inspired by some dystopian cartoon productions and the main characters were inspired by the Bible and some sacred Hindu narratives. An explicit reference to Baudrillard reveals an ideological dimension of the film. We may speculate about many more references, but what is important to stress is that before Matrix such sources were external or quite marginal to the canon of SF movies: all this was periphery. The creation of Matrix was the first leap in the direction of the centre of the semiosphere of such references. The text as a semiotic operator, a boiling pot of signification, puts all those scattered colourful cultural ingredients into a uniquely organized system and displays them to the public. This organized semiotic system does not rely entirely on any concrete pre-existing code of expression, but its successful acceptance by the inhabitants of the cinematographic semiosphere provokes interference with the dominant standards of the centre.

2 Murray, Emily 2019. 20 years ago today, The Matrix changed cinema forever. Unilad. Viewed 3 February 2020 https://www.unilad.co.uk/featured/20-years-ago-today-the-matrixchanged-cinema-forever/. 
In other words, thanks to their superior aesthetic sensibility, endowment, and experience, the movie's creators (as is the case with any other artist) were able to collect the cultural ingredients from the periphery that are vivid and charged with fresh meaning, where, without their intervention, everything would remain unperceivable for the majority of the semiosphere's inhabitants. Consequently, the movie conquered the collective imaginary. Given its aesthetic and emotional impact, it became a valid inspiration for video game developers, fashion designers, commercial video advertisers, fandom video production, TV show producers, popular jokes, etc. - all forms of creative translation, i.e., the semiotic metabolism. This illustrates how the semiotic establishment of the text proceeds. The more its establishment proceeds, the more its innovative energy is consumed, but its influence moves closer to the centre.

The establishment of the text proceeds with its symbolic metabolization. It begins when explicitly verbal and written forms of discourse start to translate the text and serve it to different audiences. Such semiotic intermediators might be the movie journalists and bloggers, trend analysts, the editors of Wikipedia, etc. The emotional and aesthetic impact of such translations is already very low, but the rational understanding of the text and its structuration grows through this process. After this phase, the text usually impacts on the dictionary of action movie making, i.e. on the established inventory of action movie effects, considered necessary and unavoidable by professional guilds and spectators. I argue that this is the case with many of the special FX innovations of Matrix (for instance, the time freeze and the bullet time effects), which have subsequently enjoyed extended use in SF and the genres that dominate the film business today. ${ }^{3}$

The force of gravity of the semiosphere's centre does not stop acting. The artistic innovation of these extraordinary works enters academic research and academic teaching of film-making. A broad variety of scholarly researchers (including semioticians) and trainers make their living on exploiting the self-descriptive meta-level of this cultural phenomenon. Thus, the phenomenon enters theoretical models, schemes, evolution charts, manuals of film directing and special FX, etc.

By imagining the semiosphere in its integrity, thousands of parallel transfers of semiotic energy from the periphery appear to feed the centre, keeping it alive and capable of serving its fundamental function: preserving socio-cultural cohesion in its dynamic multiplicity. The centre has the tendency to stabilize these semiotic processes, to structure and transform them into laws, which is however

3 Kill Bill, Inception and Minority Report among many others, according to Murray, Emily 2019. 20 years ago today, The Matrix changed cinema forever. Unilad. Viewed 3 February 2020 https:// www.unilad.co.uk/featured/20-years-ago-today-the-matrix-changed-cinema-forever/ 
a never-ending process whose interruption would bring about the semiosphere's death. In Lotman's words, "completely stable invariant semiotic structures do not exist at all" (Lotman 2009: 114).

The last element of the semiosphere model's essential synthesis is the boundary. Boundary divides what is internal to the semiosphere, as heterogeneous as it might be, from what is external and alien to it. The easiest and most formal example may be a word from a foreign language which does not fit the phonetic system of the host language and, hence, cannot enter as a part of any meaningful message. But when it comes to cultural boundaries, things get far more complicated. The boundary is a fundamental, internal necessity of the semiosphere. For a given culture or semiosphere to constitute its internal order, values, and laws, it needs a permanent reference to its own negation, its "customized" chaos. Among the numerous and most varied examples given by Lotman, there are boundaries constructed to separate the Hellenic world from the external chaos of the barbarians; the Kievan Christian world from the pagan Slavic tribes; the subconsciousness for the sake of the consciousness (Lotman 2005: 212); the dangerous transgressive chaos of homeless and drug-addicted people's nightlife from the safe order of the home (Lotman 1990: 140), the living from the dead, etc., accompanied by an infinite number of literary examples.

The second basic function of the boundary is to constitute itself as a semiotic filter for the semiosphere. As the membrane of the living cell, the boundary lets what is semiotically digestible inside the semiosphere and keeps all the rest outside. This is the first instance of translation; it is where external influences interact with the semiosphere's interior. The boundary/filter opens the possibility for a dialogue, penetration, and, finally, absorption of one semiosphere into another. The colourful and marked content of the periphery, which affords the semiosphere's innovative energy can be either internally generated by trends and other dynamic processes or brought from the outside because of the fundamental function of the boundary.

In the case of Matrix, some important creative interferences occur between various pop arts in none of which the movie is a pioneer. The concrete cartoon/ manga/anime inspiration of the authors is a source of part of the stylistic innovation of the movie, translating the dystopic tones of the source art into the language of SF cinema. Still, maybe the most interesting intrasemiospheric interference is between the filmic art and the digital world of videogames. In the 1970s, when the graphics level of videogames was rudimentary and cinematographic art was living probably its most glorious decade, the last decade before the advent of digital FX, the two semiospheres were remarkably distinct, at least on the level of mainstream pop culture. The breakthrough took place in 1982, with the cult 
movie Tron, whose storyline is situated within a videogame. Since then, the two spheres have been merging, first as parallels benefitting from the advancement of digital visualization technologies, but subsequently as unified artistic and business ventures. Matrix is a landmark in the merger of these two semiospheres, catalysing the penetration of advanced graphic videogame stylistics in the language of SF action movies, but also bringing its unique cinematographic FX into the production techniques of high budget videogames.

\section{The platfospheres}

I use the term 'platfosphere' to refer to any internet User Generated Content (UGC) platform seen, from a semiotic perspective, as a semiosphere. UGC represents the main feature of the Internet starting with the mid-2000s, known also as the Web 2.0. From my perspective, this represents the turning point, a cultural explosion (to use Lotman's notion) when Internet technology began penetrating the socio-cultural fabric of contemporary society, especially affecting digital natives. In 2004, one of the great visionaries of that phase of the Internet's development defined the new Internet as a platform where "customers are building your business for you". 4 For the moment I will leave "business" aside, although it will turn out to be the crucial theme, and will focus instead on the ideological implications of that turning point of the way the Internet was used.

In the first phase of the mass use of the Internet, from the mid-1990s until Web 2.0, the creators of content were limited in number, and the model of use was that of a new level mass media - few creators of content trying to attract as many users as possible. The average user was a consumer of useful information or entertainment, without significant options for real interpersonal interaction. During this period, the terms 'Digital age' and 'Information age' were synonyms, and the Internet's power was to augment the range of existing institutions like university networks, libraries, research centres, bureaucratic institutions, but, most of all, retail business. The Internet quickly became the biggest shopping catalogue in the world, and, gradually, the biggest virtual shopping mall. At the same time erotic and pornographic repositories began to flourish, reaching a point when experts were claiming that half of the Internet was composed of pornography.

4 Battelle, John; O'Reilly, Tim 2004. Opening welcome: State of the Internet industry. Web 2.0 conference, San Francisco, California, October 5.

5 Kushner, David 2019. A brief history of porn on the Internet. Wired. Viewed 3 February 2020 https://www.wired.com/story/brief-history-porn-Internet/. 
The passage towards the UGC was anticipated and prepared by Google. Before Google, Yahoo was the major search engine, consolidating its dominance on the very useful hierarchical classification of all exiting content (Bankov 2010). From the Yahoo front page, the user could navigate from more general categories like Arts, Business, Computers, Education, etc., towards their more articulate subcategories, and finally toward concrete websites at the end of the information tree. This was a centralized Aristotelian-type enterprise to put the Internet world in ordered and accessible form. But the exponential growth and complexity of the Internet put the model in crisis and brought the rise of Google's page ranking algorithm. With this algorithm, search results were no longer ordered according to a centralized selection of the company, but according to the success each page had among other users. The more links towards a given page there were on independent websites, the higher their rank and their chances to appear on the first page in every new query on that topic. The page ranking was completed by the account of a page's success, after users had been directed towards it searching for given content. Google's smart algorithm relies on users' activity to improve the quality of their service for these same users. (Battelle 2005; Bankov 2010)

Web 2.0 came into existence when the value people were receiving from the Internet was no longer created by big companies, but rather by other users. These big companies gradually became intermediators and regulators of that exchange, and their platforms became gradually the arena of all levels of social interaction, not only for instrumental use of information and access to entertaining content from big providers. In light of Floch's (2001: 120) well-known semiotic model, Web 1.0 as part of the socio-culture was valorized with instrumental values, whereas Web 2.0 also encompassed the Internet population's existential values. In Hartley's terminology this is the shift from the phase of the productive user to that of the Homo nuntius - the messaging identity (Hartley 2012, Ch. 8). From the origins of its existence the Internet has been resembling, in many regards, the semiosphere, but only with its Web 2.0 phase did the Internet acquire the functions vital for Lotman's modelled socio-cultural processes. There is a striking similarity to one of Lotman's descriptions of the semiosphere and the present-day social platforms of the Facebook type:

Imagine a room in a museum, where exhibits from different eras are laid out in different windows, with texts in known and unknown languages, and instructions for deciphering them, together with explanatory texts for the exhibitions created by guides who map the necessary routes and rules of behaviour for visitors. If we place into that room still more visitors, with their own semiotic worlds, then we will begin to obtain something resembling a picture of the semiosphere. (Lotman 2005: 213-214) 
Currently, Facebook has 2.7 billion registered users; YouTube has 1.9 billion; Instagram, 1.0 billion; WhatsApp, 1.3 billion; WeChat, 1.083 billion; the list of highly impactful social media platforms continues. ${ }^{6}$ With 3.484 billion active social media users, i.e., individuals involved in platform-based socio-cultural interaction, and with more and more time and commitment dedicated to it, this is historically the most relevant global transformation. From my perspective from the inventory of semiotics, there is no more adequate model for its analysis than the semiosphere.

\section{Semiosphere vs platfosphere}

I now investigate the analogy or, even, homology between the classic semiotic model and its occurrence in the digital age.

\section{Boundary}

Platfospheres have strict and formal boundaries, which help not only analysis, but also by their internal semiotic functioning. There are at least two directions where the boundary can be identified: (1) the URL, which directs to the servers where the software and the data of the platfosphere are stored; and (2) all existing interfaces of the platform that allow users to access the services, to interact, upload and download content, chat, etc.

The first type of boundary derives from the legal protection of the website, making it easy to distinguish what is behind the domain name and what is not. Everything which follows 'facebook.com' or 'google.com' is part of their respective platfospheres, and what is not behind this domain name is not (although there might be pages with closely related content, or even embedded fragments of the platfospheres), but this is already a question of the interface.

These platforms' interfaces represent a well-defined filtering device for each platfosphere, which is the most vital function of the boundary. The interface establishes a protocol of exchange which determines what kind of digitalized content from the external world can penetrate the system and what kind cannot. It also determines the level of creativity and unpredictability which users can import into the system. On Facebook, for instance, one can import a huge variety of audiovisual content and can interact with the other users in many ways, whereas on Tinder all those options are made very limited. This is reflected by the internal

6 https://thenextweb.com/contributors/2019/01/30/digital-trends-2019-every-single-statyou-need-to-know-about-the-Internet/. 
semiotic dynamics of the system, without any kind of correlation of what is better or worse. The number of users and the extent of their commitment to the platform is the only measure of the platfosphere's vitality.

\section{Periphery}

As in Lotman's "original" semiosphere, the platfosphere's periphery is not an independent entity but a term in a dynamic, asymmetric relation with the centre. Spatially we may imagine it as the manifold population of users, sparse on the globe, opposed to the centralized program code on the servers as a centre. This is what Nöth (2015, quoting Ibrus' PhD dissertation) more or less suggests in his proposal for a topography of the digital semiosphere, putting the providers at the centre. However, to grasp the essential function of the platfo-periphery requires a more sophisticated approach. Actually, the periphery is not made by the physically present users, but by their input, filtered by the interfaces. And not all users behave in an asymmetrical way to the centre. There is a critical mass of users who routinely use the platform exactly as it is designed to be used at the present moment and would not change anything in it. Still, platforms are living cultural organisms and semiospheres, and innovation is their way of being. The major drive for change in the platfosphere comes from its more creative or enterprising users who see opportunities for self-expression, social interaction, or business where even the platform's creators have not (this point comes very close to Hartley's notion of distributed networked creativity - Potts et al. 2008). Those trends are expressed in non-conventional ways as creative efforts to overcome the limitation of the interface (for instance, graphically adding peoples' names on the photo before the tagging option was introduced), or as comments and negative evaluation of the existing design of the platform, or as a direct contact with the administrators, or simply as migration to other more trending platforms which very soon will be purchased and integrated in the big ones. If, for example, we take a look at the timeline of major innovations to Facebook or YouTube, I will not hesitate to claim that these occurred as a process of creative translation from the periphery towards the centre with the above-described semiotic metabolism, partly as internal trends and partly as external influences:

\section{Facebook:}

- 2006 September 6 Facebook launches News Feed. The original news feed is an algorithmically generated and constantly refreshing summary of updates about the activities of one's friends. 
- 2007 January 10 Facebook launches $\boldsymbol{m}$.facebook.com and officially announces mobile support.

- 2007 May 24 Facebook announces Facebook Platform for developers to build applications on top of Facebook's social graph.

- 2009 February 9 Facebook introduces the Like button.

- 2011 September 22 Facebook launches new UI Timeline.

- 2013 April 9 Facebook rolls out detailed and fine-grained emoticons to express different actions and emotional states in one's status updates.

- 2013 July Facebook launches Stickers.

- 2014 January 16 Facebook launches Trending Topics for its web version.

- 2015 May 29 Facebook confirms official support for GIFs.

- 2016 March Facebook Live that was originally limited to celebrities, becomes available to all.

- 2016 February 24 Facebook releases Facebook Reactions to the general public which are 'love, 'haha', 'wow', 'sad', and 'anger'.

- 2017 March 23 Facebook adds reactions and mentions inside Messenger.

- 2017 May 24 Facebook Fundraising is launched.

\section{YouTube}

2005 July - Video HTML embedding

2005 July - Top videos page

2005 August - 5-star rating system

2005 October - Playlists

2006 January - Groups function

2006 February - Personalized profiles

2006 April - Directors function

2006 May - Video responses

2006 May - Cell phone uploading

2006 June - Viewing history

2007 June - Local language versions

2008 December - Audioswap

2009 December - Automatic speech recognition

2010 March - 'Thumbs' rating system

2011 November - Feature film rental

2012 October - YouTube live stream

Etc.

(The timelines are adapted from Wikipedia and report the facts as supported by references to evidence there.) 


\section{The centre}

The centre of the platfosphere is obviously its code, the multitude of software systems and databases installed on the servers and on users' devices which juridically define the platform and practically enable access to its services. The code dictates the rules of the platform and represents its grammar of interaction and conditions of use. In 1977 Barthes claimed that language is a fascist for thought (Barthes 1978), but the dictatorship of Internet platforms is even more significant. Here we are obviously speaking of the formal rules of semiotic expression and not about the role of modelling systems for a democratic process. The platfosphere's centre is invisible to its users, beyond the code constituting its embodied rules which act unconsciously as a habit and represent what users' expectations take for granted. An important part of those core rules is common among many platfospheres and can be seen as the primary modelling system for general digital literacy. Another part of the centre is made of the specific rules coded for each platfosphere, and successful innovations which the users easily get used to, soon forgetting that these were not there before usually falling into this category. For instance, we are so used to the Like button on Facebook or the 'Thumbs' rating system on YouTube that we cannot imagine the platforms without them, but actually both appeared five (!) years after the social networks started operating.

Logically, the last question is this: what might be the metalevel of platfospheres' self-knowledge, the core of their centres? In the semiosphere model the metalevel belongs to semioticians, to linguists and grammar researchers, to cultural historians and any kind of scholars capable of theoretic reflection, modelling, and academic teaching on the principles of culture. The easy answer would be that platfospheres' metalevel of self-knowledge belongs to the scholars of informatics, programming and computer science, but it would be too simplistic to end this study with a full list of similarities. A careful examination of the platphosphere's metalevel shows fundamental differences from the semiosphere, and justifies a deeper reflection on the differences.

\section{Reflections on the DNA of digital culture}

Before continuing I need to make it clear in what way the notion of DNA is used to avoid unexpected misunderstandings of the kind that occurred during the preparation of the paper. All comes from a coincidence with the very popular theory on the cultural DNA and the book by Gurnek Bains (2015) bearing the title. Bains draws important definitions of cultural invariants determined by 
environmental and genetic factors, which seem helpful in their original context of organizational culture, but are strongly debatable if considered in cultural science and humanities. So my use of the notion of cultural DNA is figurative, although much deeper than a mere rhetorical figure. It is a continuation of the heuristic analogy/homology between the biosphere and the semiosphere, as launched by Lotman, without any causal relation and determination of the intellectual by the biological.

Thus, to understand my point about the comparison between the self-knowledge meta-level of "digital" and "classic" semiospheres, we need to look at the ideological contexts of the two epochs. Although Lotman gives some cinematic examples, media and other cultural phenomena contemporary to him, the main source of inspiration for the semiosphere model, lies in the elitist cultures of traditional societies and intelligentsia of the nation state, where a small minority of literate and very insightful people shaped the essence of culture and where cultures were quite separate, influencing each other only where geographically possible. Cultural essences radiated from the centre to the periphery, and intercultural influences were registered and studied on the base of those elite writings.

When the modern university was conceived by Humboldt and Fichte and first implemented at the University of Berlin, in the first half of the 19th century (and then spread all around Europe), a new category of metacultural agents was introduced on top of this cultural "nutrition chain" - the university professors. The mission of this category was "to provide the metadiscourse that legitimates and organizes all knowledge" (Readings 1996: 66, my emphasis, K. B.) and thus to have a leading role in the progress of the nation state. In that cultural atmosphere this mission was underestimated by no one, since this new social cohesion, solidarity, and policy-making were functions of the imagined community's efficacy (Anderson 1983) - in other words, the efficacy with which the education system was capable of standardizing the language, the grand narrative of the founding fathers and the Enlightenment. The university was the incubator of the national culture's self-knowledge, or its metalevel, and although philosophers were put on top of the system in the first idealistic frame, gradually the study of national literature assumed the leading role for the intelligentsia (Readings 1996, Ch. 6, 76).

The university model during the Cold War (on both sides) was a continuation of this Humboldtian project, notwithstanding the completely changed political agenda (especially in the East). The importance and prestige of the study of national literature and culture were nonetheless still immense, and when Lotman refers to the metalevel of self-knowledge of the semiosphere this relies on an ideology of the humanities' implicit superiority among the other fields of academic knowledge, which, in my modest opinion, was justified. 
The big difference between this and today's situation is that throughout the course of the modern university, the subject of semiospheres' metalevel - the languages, literatures, arts and all other cultural issues were open, available or ready to be discovered by academic research. Today, however, what is the effective centre of the platfospheres - a program's code and big data - is hidden, secret, and protected by the patents of the giant corporations - their private property. Previously, the university held a monopoly on knowledge; today the real professional formation (and there is no other) of those designers of the platfosphere's centre takes place far from academia, behind the locked doors of companies, and protected with contracts of confidence. Academic researchers today may study (and indeed we do) the external occurrence of the platfospheres' centre, their impact on our socio-culture, language and lifestyles, but when it comes to self-knowledge we can only guess. And we will see that this guessing has become an industry, not only for academics, and such a paradox has never before existed in the history of semiosphere theory.

What I think is closest to the semiosphere's metalevel of self-knowledge in the platfosphere is the algorithm. We can understand the role of algorithm if we have a look at the definition of an Internet platform:

A platform is a business based on enabling value-creating interactions between external producers and consumers. The platform provides an open, participative infrastructure for these interactions and sets governance conditions for them. The platform's purpose is to consummate matches among users and facilitate the exchange of goods, services, or some sort of social currency, thus enabling meaningful value exchanges between all participants. (Parker et al. 2016: Ch. 1; my emphasis, K. B.)

If we look behind the business terminology above, we may see platforms as a technological intermediator and accelerator of social life in all its parts. As mentioned before, we may group all our needs into instrumental (goods, services, etc.) and existential (creating and affirming our social ego) ones, and when it comes to the latter, everyone is a perpetual producer and consumer at once. "Attention, fame, influence, reputation, and other intangible forms of value can play the role of 'currency' on a platform" (Parker et al. 2016: Ch. 1). Platforms as Facebook, Instagram and Twitter are predominantly of the second type; YouTube, WeChat and Tinder are balanced between the two types of value; Amazon, Airbnb and Uber are predominantly about the exchange of instrumental value. The "secret magic" of these huge and very successful platforms comes from the particular ways in which they arrange exchanges (or matches) between their users, and it is called algorithm. 
Algorithm is unavoidable, insofar as on all platforms one can find more offers than one's cognitive capacity allows to consider. The usability of the system requires that users are exposed only to a small selection of these offers, and the big challenge for the owners of these platforms is how to provide each user with the offers most relevant for them. The algorithm is both the key to business success, and the instrument through which the platform shapes our socio-cultural reality. The algorithm is responsible for what news and personal stories I will see on my Facebook and Instagram newsfeeds, a selection among millions of possibilities, which strongly conditions my further interactions; on Tinder I can see profiles for potential matches which are selected by the algorithm according to criteria, challenging one of the biggest mysteries of human nature - the selective affinities; on Amazon all users continuously receive suggestions to purchase goods and services, calculating their entire buyer's records and the choices of others like them.

I call these algorithms the meta-level of the platfosphere's self-knowledge, because they operate as a structuring device upon a huge textual massif known as Big data - the raw digital record of users' overall experience with a platform. Big data cannot be implemented in their raw state, but with the help of different type of algorithms and through a process called data mining, valuable cultural patterns can be extracted from them, as well as many other types of metainformation through which platforms operate and innovate their own design and functions. From a certain point of view, data mining corresponds to the work Humboldt's university professors were supposed to do with the available cultural, linguistic, and historical information. However, the core motivation for producing this selfknowledge metalevel is completely opposite.

The conception of the modern university was idealistic. Its unconditional independence from the state (despite the requirement of generous funding) and the untouchable academic freedom it promised within the academy were the premises to achieving its major goal - the ideal of absolute knowledge (Readings 1996: 69). We can hardly think that a state-funded university was ever entirely independent, but what was certainly achieved was the university's independence from the market. The semiosphere model preserves this spirit and, as I mentioned in the opening paragraphs, finances and economic issues were somehow completely alien to an understanding of the phenomenon of culture and humanities' inquiry of it. On the contrary, web platforms are all about money and economic value. If Internet platforms shape the 21 st century's global culture just as universities were shaping national cultures in the preceding 200 years, and the statistics can only confirm this assumption, then the "genetic material" of the platfosphere is that of a different species than Lotman's semiosphere. 


\section{The sociocultural impact of one platform}

I will give an example of how the various levels of the platfosphere interact in their commercial logic, and thus bring about a substantial cultural change. According to some observers, digital dating platforms have profoundly changed our society, causing "the second greatest shift in human sexual habits, second only to the establishment of marriage" (Justin Garcia ${ }^{7}$ ). Tinder with its 50+ million subscribers is the most famous among such platforms and, for many, its algorithm caused the sexual cultural explosion of the last decade. Tinder's basic algorithm is unique with the choice of swiping left or right, giving a particular sense of sexuality's commodification while experiencing its interface. We may assume that Tinder's initial design grasped some trends and attitudes from the periphery of the platfosphere, where many other dating apps have not, despite having shaped the digital sexual culture of a decade earlier. Tinder's algorithm relies on few features as essential as geographical proximity, the emotional charge of the first impression: it prevents undesired attention, opening a chat option only when both sides have swiped left ("liking" each other), thus offering a high number of desirable prospective matches.

The combination of these features worked, and the algorithm's prime challenge was to preserve the frequency of quality matches despite a growing number of subscribers; and the possibility for endless swiping without a match would have been frustrating and harmful for the platform's overall reputation. The algorithm's designers had to work with the big data of existing swipes, matches, and users' profiles in order to establish a metalevel of information, indicating automatically which profiles would most probably be mutually liked in order to be listed first after their holders begin swiping. As I mentioned above, Tinder's algorithm challenged one of the big mysteries of human nature, which scientists have never been able to answer unanimously: the criteria for visual attraction among individuals. I guess that the academic scholars of that matter can never have a database of 1.6 billions of swipes a day (record of a concrete person liking or not the profile of another person), 24 million matches a day and an overall record of 8 billion matches since the platform was launched. ${ }^{8}$ "Tinder professors" in their Big data laboratories obviously grasped something of the laws of mutual attraction and succeeded to produce an ever-developing algorithm which achieved the goal of enticing the biggest number of users on a dating platform, and to keep them using it.

Once the social trend passed from the platfosphere's periphery to its core, it started to shape a new culture. In the collective imaginary, Tinder established

7 Agnew, Roisin 2015. Love me Tinder: How technology is changing sex. The Irish Times, Sept. 18.

8 https://en.wikipedia.org/wiki/Tinder_(app). 
itself as the easiest way to have intimate relations with decent people of your liking. Something which was previously a privilege for a few and a desired opportunity for many became a tangible reality for everybody. A new lifestyle emerged, putting in crisis not only marriage, ${ }^{9}$ but the very possibility of long-term intimate commitments of the whole millennial generation as well. ${ }^{10}$ Not Tinder alone, to be sure, but the overall impact of the so-called "hook-up culture" catalyzed and provoked by Tinder led many new and even better platforms to emerge, and the old ones to improve.

When we say that the DNA of the classic semiosphere and the DNA of the platfosphere are of different species, one of the dimensions is that the old one is passive, limiting itself to establishing norms and standards necessary for the social life of culture, whereas the platfosphere's core is pro-active: it speaks to every user individually, it spams, it auto-generates content and tries to consume as much as possible from the resources of time and money of its users, which is its reason for existence. An easy analogy can be made to the nature of the living cell, some of which divide their DNA in a regular way while others assume an aggressive or expansive way to multiply with uncontrollable DNA mutations (to put it without any pejorative connotation, if possible).

Tinder's fortune may have come from cracking the mystery of human attraction, but science and "the pursuit of absolute knowledge" have hardly benefitted from it. Algorithms have the necessity of code protection and secrecy within their "cultural" DNA, ${ }^{11}$ as far as both competitor platforms and marketing agencies would immediately take advantage and weaken their business. For the same reason platforms may deliberately subvert the interests of the public. For instance, a particular setup of Tinder's powerful algorithm may promote long-lasting relations and marriage, which may promote better quality family life, more harmony, and stability in society. But in the long run such a setup would be suicidal for the platform, and thus the Tinder algorithm promotes the "ethos" of the hook-up culture with all its means, sometimes causing what is already being diagnosed as "Tinder addiction". ${ }^{12}$

9 Mostly in Western countries, see Stuessy, Nicole 2017. Study: 'Cheap sex' has led to decline in marriage. The Daily Texan. viewed 3 February 2020 https://thedailytexan.com/2017/10/12/ cheap-sex-has-led-to-decline-in-marriage.

10 The FOMO phenomenon; for instance, see Vuzharov 2019.

11 Staaben, Katelyn 2018. Unlocking the secrets of social media algorithms. Viewed 3 February $2020 \mathrm{https} / /$ www.northwoodsoft.com/Blog/Unlocking-the-Secrets-of-Social-MediaAlgorithms.htm.

12 Sinrich, Jenn 2018. Tinder Addiction is real: How to spot signs you're a victim. Datezie. Viewed 3 February 2020 https://www.datezie.com/tinder-addiction-is-real-how-to-spotsigns-youre-a-victim/. 
Wikipedia might be considered an example of a successful platfosphere which is quite close to the culture of erudition, inherent in the model of the semiosphere, with almost no shadow of doubt of its public benefit (yet not very much appreciation by the majority of professional scientists and academics either).

The algorithm of Facebook, the most profitable of all social networks (although partially revealed for PR reasons) is in fact the most protected one. If cracked by marketing agencies it would be abused, and in a few months all users would see hidden corporate information infiltrating the platform's content to satisfy their informatic and egotistical needs. The algorithm is as powerful as it is because it goes straight to the heart of our social/existential needs, representing the most accessible (for us and for the rest of the 2.7 billion users) way to construct and manage our identity. Since Simmel (1957), it has been known that the social identity is driven dialectically by two opposing forces - conformity and individualism - and Facebook provides almost the perfect conditions for both. When it comes to identity, its construction and affirmation does not happen in a passive or contemplative way, but requires persistent interaction with others. As we pointed out at the beginning, platforms encourage interaction, besides goods and services, with various types of "social currency" which may be "attention, fame, influence, reputation, and other intangible forms of value" (Parker et al. 2016, Ch. 1). Thanks to Todorov (2001) we know that recognition, with all its occurrences, can be the common denominator of all the ego exchanges for which people are insatiable.

What the algorithms of Facebook do is capitalize on the infinite trade of recognition and monetize it afterwards, selling each consumer's predisposition to companies. To acquire richer profile data, Facebook's algorithm does not leave the recognition trade to its spontaneous course, but promotes a user's profiles and activities with its proactive platfosphere centre, independently of their preference. Furthermore, the algorithm increases the chances for a recognition exchange like likes, comments, shares, tags, etc., taking care that every user is exposed only to the most likeable, shareable and commentable content, chosen from among millions of other selections. The algorithm thus distorts the perception of reality and the potential for critical interaction with the offline world closing its users into so-called "eco chambers". 13

13 Knight, Megan 2018. Explainer: How Facebook has become the world's largest echo chamber. The Conversation. Viewed 3 February 2020 https://theconversation.com/explainerhow-facebook-has-become-the-worlds-largest-echo-chamber-91024;

Quattrociocchi, Walter 2017. Inside the echo chamber. ScientificAmerican.com. Viewed 3 February 2020 http://web.csulb.edu/ plowentr/Inside\%20the\%20Echo\%20Chamber.pdf. 


\section{Results and conclusions}

The cultural mechanism of the platfosphere reveals how the social media platforms are the most successful instrument for social engineering, with a significantly big concentration of cultural shaping power in the hands of their owners. They bring trends and attitudes from the periphery to the centre of the platfosphere with accelerated intensity proportional to their prospective profits. The platfospheres institute these trends and attitudes as a cultural norm, as what is taken for granted in our everyday life and what shapes our shared expectations for good living. In this way the average social media users who spend a lot of their time there embody socio-cultural habits which are remotely engineered and fine-tuned over time by the designers of social media algorithms, which are usually coded for the addictive satisfaction of short-term instrumental and egoistic needs and a long-term prospect of profit maximization. In extreme cases this might resemble a wireless version of a string puppet. Such is the cultural and normative DNA installed by the accelerated semiotic life of the platfosphere, and although I am not going to take an ethical stance here, I cannot help but agree with the ethical stance of Jeremy Rifkin, who envisions exactly the same phenomenon when he makes this key claim in his seminal book The Age of Access:

Restoring a proper balance between the cultural realm and the commercial realm is likely to be one of the most important challenges of the coming Age of Access. Cultural resources risk overexploitation and depletion at the hands of commerce just as natural resources did during the Industrial Age. (Rifkin 2000: 7):

In this challenge, I think, semiotics can compete with other academic disciplines on equal merits, following the important critical tradition of Barthes and Eco, and relying on academia as the last fortress of cultural resources in a time of extinction.

\section{References}

Anderson, Benedict 1983. Imagined Communities: Reflections on the Origin and Spread of Nationalism. London: Verso.

Bains, Gurnek 2015. Cultural DNA - The Psychology of Globalisation. New Jersey: John Wiley \& Sons. https://doi.org/10.1002/9781119209461

Bankov, Kristian 2010. Cultures of navigation versus cultures of erudition. Lexia 05/06 (Analisi delle culture, culture dell'analisi): 103-123.

Bankov, Kristian 2017. Eco and the Google Search innovations. In: Thellefsen, Torkild; Sørensen, Bent (eds.), Umberto Eco in His Own Words. (Semiotics, Communication and Cognition 19.) Berlin: De Gruyter Mouton, 119-126. https://doi.org/10.1515/ 9781501507144-015 
Bankov, Kristian 2019. Cultural transformations of love and sex in the digital age. Digital Age in Semiotics and Communication 2: 7-17. https://doi.org/10.33919/dasc.19.2.1

Bankov, Kristian 2020. Scarcity and meaning: Towards a semiotics of economic transaction. In: Cobley, Paul; Olteanu, Alin (eds.), Semiotics and its Masters. Vol. 2. (Semiotics, Communication and Cognition.) Berlin: De Gruyter Mouton. (In print.)

Barthes, Roland 1978. Leçon inaugurale de la chaire de sémiologie littéraire du Collège de France. Paris: Seuil.

Battelle, John 2005. The Search: How Google and Its Rivals Rewrote the Rules of Business and Transformed Our Culture. London: Brealey.

Bergson, Henri 1992. The Creative Mind: An Introduction to Metaphysics by Henri Bergson. New York: Carol Publishing.

Bruni, Luis E. 2011. Cognitive sustainability in the age of digital culture. Triple C: Communication, Capitalism \& Critique 9(2): 473-482. https://doi.org/10.31269/triplec.v9i2.301

Bruni, Luis E. 2015. Sustainability, cognitive technologies and the digital semiosphere. International Journal of Cultural Studies 18(1): 103-117. https://doi.org/10.1177/ 1367877914528121

Derrida, Jacques 1982. White mythology: Metaphor in the text of philosophy. In: Derrida, Jacques, Margins of Philosophy. Chicago: University of Chicago Press, 207-272.

Eco, Umberto 1990. Introduction. In: Lotman, Juri 1990. Universe of the Mind: A Semiotic Theory of Culture. Bloomington: Indiana University Press.

Floch, Jean-Marie 2001. Semiotics, Marketing and Communication. New York: Palgrave.

Foucault, Michel 1977. What is an author? In: Foucault, Michel, Language, CounterMemory, Practice: Selected Essays and Interviews by Michel Foucault. New York: Cornell University Press, 113-138.

Hartley, John 2012. Digital Futures for Cultural and Media Studies. Malden: WileyBlackwell. https://doi.org/10.1002/9781118106723

Hartley, John; Potts, Jason 2014. Cultural Science: A Natural History of Stories, Demes, Knowledge and Innovation. London: Bloomsbury.

Hartley, John; Wen, Wen; Li, Henry Siling 2015. Creative Economy and Culture: Challenges, Changes and Futures for the Creative Industries. London: SAGE. https:// doi.org/10.4135/9781473911826

Ibrus, Indrek 2014. Path dependencies in media design: Evolutionary dynamics of early mobile web and its textual forms. Social Semiotics 24(2): 191-208. https://doi.org/10.1 080/10350330.2013.859479

Ibrus, Indrek; Scolari, Carlos A. (eds.) 2012. Crossmedia Innovations: Texts, Markets, Institutions. Hamburg: Peter Lang. https://doi.org/10.3726/978-3-653-02575-0

Ibrus, Indrek; Torop, Peeter 2015. Remembering and reinventing Juri Lotman for the digital age. International Journal of Cultural Studies 18(1):3-9. https://doi.org/10.1177/ 1367877914528113

Lotman, Juri 1990. Universe of the Mind: A Semiotic Theory of Culture. Bloomington: Indiana University Press.

Lotman, Juri 2005. On the semiosphere. Sign Systems Studies 33(1): 205-229.

Lotman, Juri 2009. Culture and Explosion. (Semiotics, Communication and Cognition 1.) Berlin: Mouton de Gruyter. 
Parker, Geoffrey G.; Alstyne, Marshall W. Van; Choudary, Sangeet Paul 2016. Platform Revolution: How Networked Markets are Transforming the Economy - and How to Make Them Work for You. New York: W. W. Norton \& Company.

Nöth, Winfried 2015. The topography of Yuri Lotman's semiosphere. International Journal of Cultural Studies 18(1): 11-26. https://doi.org/10.1177/1367877914528114

Potts, Jason; Cunningham, Stuart; Hartley, John; Ormerod, Paul 2008. Social network markets: A new definition of the creative industries. Journal of Cultural Economy 32(3): 167-185. https://doi.org/10.1007/s10824-008-9066-y

Readings, Bill 1996. The University in Ruins. Cambridge: Harvard University Press. https:// doi.org/10.2307/j.ctv1cbn3kn

Rifkin, Jeremy 2000. The Age of Access: The New Culture of Hypercapitalism, Where all of Life is a Paid-For Experience. New York: Penguin/Putnam.

Simmel, George 1957. Fashion. American Journal of Sociology 62(6): 541-558. https://doi. org/10.1086/222102

Todorov, Tzvetan 2001. Life in Common. Lincoln: University of Nebraska Press.

Vuzharov, Mihail 2019. UX \& FOMO: Looking for love or looking for options? Digital Age in Semiotics and Communication 2: 77-91. https://doi.org/10.33919/dasc.19.2.5

\section{Movies}

Inception. 2010. Dir. Christopher Nolan. Warner Bros. Pictures.

Kill Bill I. 2003. Dir. Quentin Tarantino. Miramax Films.

Kill Bill II. 2004. Dir. Quentin Tarantino. Miramax Films.

The Matrix. 1999. Dir. Andy Wachowski and Larry Wachowski. Warner Bros. Pictures.

Minority Report. 2002. Dir. Steven Spielberg. 20th Century Fox.

Tron. 1982 Dir. Steven Lisberger. Walt Disney Productions.

\section{«Платфосферы» и социокультурный взрыв Web 2.0: коммерческая основа дигитальной семиосферы}

В этой статье цифровая культура исследуется с помощью инструментов семиотики культуры и, в частности, с помощью модели семиосферы. Большая часть населения мира в данный момент окружена цифровой культурой. В первой части статьи отмечается поразительное сходство между платформами Web 2.0 и семиосферой и выявляется эквивалентность классической семиотической модели Лотмана этим платформам или «платфосферам». Во второй части рассматривается фундаментальное различие между «генетическим кодом» в центре лотмановской семиосферы и компьютерным кодом и коммерческими алгоритмами в центре платфосферы, которые обеспечивают их функционирование в культуре. Затем прослеживаются параллели, возникающие при сопоставлении реалий культуры прошлого, когда интеллектуальная элита и ученые были движущей силой культуры, и современным проактивным (или даже агрессивным) ядром платфосфер, в котором секретные и защищенные патентами алгоритмы формируют культурную реальность, мотивированную исключительно логикой коммерческого успеха. 


\section{Platfosfäärid ja Web 2.0 ühiskondlik-kultuuriline plahvatus: digitaalse semiosfääri kommertslik kese}

Artiklis käsitletakse digikultuuri nii üldiste kultuurisemiootika vahendite abil kui ka konkreetselt semiosfääri mudelit rakendades. Suuremat osa maailma rahvastikust ümbritseb praeguseks digikultuur. Artikli esimeses osas vaadeldakse rabavaid sarnasusi Web 2.0 platvormide ja semiosfääri vahel ning tuvastatakse ekvivalentsused (Lotmani) klassikalise semiootilise mudeli ning nende platvormide ehk platfosfääride vahel. Teises osas käsitletakse fundamentaalset erinevust ühelt poolt (Lotmani mõistes) semiosfääri keskmes asuva "geneetilise koodi" ning teisalt platfosfääride tuumas asuvate ja nende kultuurilist toimimist tagavate kommertslike algoritmide ja arvutikoodide vahel. Seejärel vaadeldakse paralleele, mis tekivad kõrvutades mineviku kultuurireaalsust, milles kultuuri liikuma panevaks jõuks olid intellektuaalne eliit ning teadlaskogukond, ning tänapäevaste platfosfääride proaktiivset (või isegi agressiivset) tuuma, milles salajased, kaitstud patentidega algoritmid kujundavad ainuüksi kommertsliku edukuse loogikast motiveeritud kultuurilist reaalsust. 